\title{
Normatiewe leiding in woordeboeke: 'n nuwe benadering.
}

\author{
R.H. Gouws, Departement Afrikaans en Nederlands, \\ Universiteit van Stellenbosch, Suid-Afrika
}

\begin{abstract}
Normative Information in Dictionaries: An Innovative Approach. In a multilingual society linguistic contact leads to language influencing which effects different registers of the language. The standard variety of Afrikaans is largely subjected to language influence resulting from its continuous contact with English. In their treatment of the lexicon dictionaries should reflect the linguistic reality. The results of linguistic contact should also be included in a dictionary. Afrikaans monolingual and bilingual desk dictionaries as well as restricted normative dictionaries have traditionally adopted a strictly prescriptive approach, endeavouring to render the standard language as a puristic variety. This resulted in a restriction of the macrostructural scope of these dictionaries.

In this paper the traditional approach is discussed in order to contrast it with an innovative approach to the lexicographical treatment of language change. The normative Afrikaans dictionary Die korrekte woord is used to illustrate the new approach. This dictionary treats the Afrikaans Iexicon in a new way by including a substantial number of English loan words. While adhering to its normative assignment Die korrekte wourd gives an account of the dynamics of language change. This is done by responding to a new interpretation of the notion "Standard Afrikaans". The application of this approach leads to the inclusion of a lemma selection that represents the real standard variety of Afrikaans. The principles applied and the implications for normative lexicography in general are discussed.
\end{abstract}

Keywords: ANGLICISM, BILINGUAL DICTIONARY, DESK DICTIONARY, DICTIONARY, FUNCTIONAL BORROWING, LANGUAGE INFLUENCE, LANGUAGE STANDARDIZATION, LEXICAL BORROWING, LEXICOGRAPHY, LEXICON, LINGUISTIC CONTACT, LOAN TRANSLATION, NORMATIVE DICTIONARY, PRESCRIPTIVITY, PURISM

Opsomming: In 'n meertalige situasie lei taalkontak tot taalbeïnvloeding. Taalbeinvloeding raak verskillende registers van ' $n$ taal. Afrikaans se standaardvariëteit word grootliks beinvloed deur die voortdurende kontak met Engels. In hulle bewerking van die leksikon van 'n taal moet woordeboeke ' $n$ weersprieëling bied van die taalwerklikheid. Die gevolge van taalbeïnvloeding moet leksikografiese vergestalting kry. Verklarende en vertalende handwoordeboeke van Afrikaans asook beperkte normatiewe woordeboeke het tradisioneel 'n streng preskriptiewe benadering gevolg en gepoog om 'n puristiese weergawe van die standaardtaal aan te bied. Dit het gelei tot' $n$ verskraling van die bestek van hierdie woordeboeke.

Hierdie artikel is ' $n$ hersiene en uitgebreide weergawe van een onderafdeling van Gouws (1993). 
In hierdie artikeI word aandag gegee aan die tradisionele benadering as agtergrond vir 'n bespreking van ' $n$ innoverende leksikografiese behandeling van taalverandering. Die normatiewe woordeboek Die korrekte woord word gebruik ter illustrasie van die nuwe benadering. Hierdie woordeboek se vernuwende bydrae is veral ter sake in sy hantering van leenwoorde uit Engels. Sonder om sy normatiewe funksie te versaak, doen die woordeboek verslag van die geldende taaldinamika. Hierdie leksikografiese behandeling spruit uit 'n ruim interpretasie van die begrip "Standaardafrikaans". Die toepassing hiervan lei tot ' $n$ lemmakeuse wat verteenwoordigend is van die werklike standaardvariëteit van Afrikaans. Die beginsels waarvolgens die nuwe benadering werk, word bespreek asook die implikasies wat dit vir die normatiewe leksikografie het.

Sleutelwoorde: ANGLISISME, FUNKSIONELE ONTLENING, HANDWOORDEBOEK, LEENVERTALING, LEENWOORD, LEKSIKOGRAFIE, LEKSIKON, NORMATIEWE WOORDEBOEK, ONTLENING, PRESKRIPTIWITEIT, PURISME, TAALBEINVLOEDING, TAALKÓNTAK, TAALSTANDAARDISERING, VERTALENDE WOORDEBOEK, WOORDEBOEK

\section{Inleidend}

Linguistiese woordeboeke moet 'n weerspieëling bied van die taalwerklikheid. Vir die Suid-Afrikaanse leksikograaf bied hierdie opdrag ' $n$ omvattende uitdaging. Om verslag te doen van die Suid-Afrikaanse taalwerklikheid beteken dat daar eweneens verslag gedoen moet word van die multitalige en multikulturele plaaslike situasie. Taalkontak lei noodwendig tot ' $n$ onderlinge beïnvloeding van die verskillende tale. Geen Suid-Afrikaanse taal bestaan in isolasie nie en geen Suid-Afrikaanse taal spring dit vry om die teiken van taalbeïnvloeding te wees nie.

Algemene verklarende en vertalende woordeboeke is veral gerig op 'n bewerking van die standaardvariëteit van die betrokke taal of tale. Ook hierdie variëteit is onderhewig aan die invloed van taalkontak. Binne 'n meertalige opset sal pogings tot taalstandaardisering erkenning moet gee aan die gevolge van die kontaksituasie. Woordeboeke sal nie net ' $n$ weergawe kan bied van ' $n$ puristiese standaardvariëteit nie maar sal ag moet slaan op die dinamika van taalverandering en die gevolge wat dit vir die omvang en inhoud van spesifiek die standaardvariëteit van ' $n$ taal het.

In hierdie artikel word daar gefokus op enkele aspekte van die leksikografiese hantering van die Suid-Afrikaanse taalkontaksituasie. Die klem is veral op die invloed wat dit op Afrikaans en op veranderinge in die tradisionele preskriptiewe perspektief van woordeboeke het. In hierdie verband word die bespreking gerig op die sewende uitgawe van die normatiewe woordeboek Die korrekte woord. Aandag word in 'n mindere mate ook gegee aan algemene verklarende Afrikaanse woordeboeke en vertalende Afrikaans-Engelse woordeboeke se benadering tot die preskriptiewe perspektief.

Weens die landswye geografiese verbreidheid van die gebruikers van Afrikaans en Engels skep die taalkontaksituasie 'n voortdurende interaksie tus- 
sen hierdie twee tale. Dit lei tot 'n wedersydse beïnvloeding wat nie tot leksikale veranderings beperk is nie maar wat ook geld op die vlak van byvoorbeeld die fonologie, morfologie, sintaksis en ortografie. Vanuit 'n leksikografiese perspektief is dit veral leksikale veranderings wat opvallend en ter sake is.

Die tussentalige wisselwerking in Suid-Afrika het 'n besliste uitwerking op die aard en omvang van voorskriftelike houdings oor puristiese taalgebruik. Dit geld veral die houding oor Afrikaans. Die ideaal om Afrikaans as ' $n$ onafhanklike taal naas die wêreldtaal Engels te laat ontwikkel, het 'n puristiese drang laat ontstaan wat gelei het tot talle pogings om die werklikheid van die taalkontaksituasie te ontken en om die invloed van Engels op Afrikaans te minimaliseer of te neutraliseer. Afrikaanse skoolgrammatikas het byvoorbeeld 'n baie sterk preskriptiewe houding weerspieël. Normatiewe woordeboeke is opgestel met die suiwering van Afrikaans as belangrike opdrag.

Gebeure van die laaste dekade of wat het egter ingrypende houdingsveranderinge meegebring. Dit het gelei tot 'n erkenning van die feit dat die SuidAfrikaanse tale saam moet bestaan, dat taalkontak 'n onontkombare werklikheid is en dat dit noodwendig tot taalverandering sal lei. Dit word ook aanvaar dat so ' $n$ verandering nie ' $n$ verlaging in die gehalte van die betrokke taal impliseer nie. Hierdie houdingsverandering het 'n nuwe perspektief op die preskriptiewe en deskriptiewe funksies van woordeboeke tot gevolg gehad. Woordeboeke moet inligting oordra wat verteenwoordigend is van die linguistiese werklikheid en wat die dinamika van taalverandering erken.

\section{Afrikaanse woordeboeke en die tradisionele normatiewe benadering}

In Afrikaanse woordeboeke is standaardisering dikwels regstreeks verbind met preskriptiwiteit en normatiwiteit. In die ontwikkeling van Afrikaans naas Engels moes elke denkbare hulpmiddel tot uitbreiding en oorlewing benut word. Vertalende Afrikaans-Engelse woordeboeke het gevolglik die klem baie sterk op puristiese Afrikaans geplaas. 'n Soortgelyke nougesette en preskriptiewe benadering is ook in eentalige Afrikaanse woordboeke gevolg. Dit geld al die subtipologiese kategorieë, onder meer handwoordeboeke, skoolwoordeboeke en beperkte normatiewe woordeboeke.

\subsection{Die beïnvloeding van die informele register van Afrikaans}

Die invloed van Engels op Afrikaans is duidelik merkbaar op die vlak van tegniese en wetenskaplike taalgebruik. Tog is die sterkste en opvallendste invloed op die vlak van die informele register van Afrikaans, vgl. Van der Merwe en Ponelis (1991: 63). ' $n$ Mens kan die aard en omvang van die invloed van Engels op Afrikaans eers reg begryp wanneer jy vertroud is met die hoë mate van tweetaligheid van die sprekers van Afrikaans. As gevolg van die status van én 
Afrikaans én Engels as amptelike landstale beskik die gemiddelde lid van die Afrikaanse taalgemeenskap oor 'n gevorderde graad van tweetaligheid. $\mathrm{Hy}$ is nie net vlot in sy moedertaal Afrikaans nie maar die kragtige uitdrukkingsvermoë van Engels en veral die uitgebreide Engelse woordeskat staan voortdurend tot sy beskikking.

Die aktiewe taalkontak in die individuele lid van die Afrikaanse taalgemeenskap lei tot 'n produktiewe oordrag van woorde en uitdrukkings vanaf Engels na Afrikaans. Sommige van hierdie leksikale items word verafrikaans deurdat hulle byvoorbeeld by die Afrikaanse grammatiese, morfologiese, fonologiese of ortografiese stelsel aangepas word. 'n Groot aantal Engelse leksikale items word as deel van die Afrikaanse leksikon geïnternaliseer. Sommige van hierdie leenwoorde het 'n beperkte optrede en die leksikograaf hoef hulle nie vir opname in die woordeboek te oorweeg nie. Sodra 'n leenwoord egter 'n gevestigde gebruik in Afrikaans verwerf het, moet dit in woordeboeke aangedui word.

\subsection{Die Woordeboek van die Afrikaanse Taal}

Een woordeboek waarin die puristiese benadering nie so opvallend is nie, is die omvattende Woordeboek van die Afrikaanse Taal (voortaan afgekort as die WAT). Die mindere mate van preskriptiwiteit in die WAT spruit regstreeks voort uit die tipologiese kriteria wat die leksikograwe van hierdie woordeboek verplig om die leksikon van Afrikaans so omvattend as moontlik te weerspieël. Dit lei tot die insluiting van 'n groot klomp inskrywings met 'n beperkte, niestandaardoptrede, bv. die volgende lemmas wat in WAT VIII verskyn: kraalnetvlerkie, kree, kruiwasaaier en kwasmot. Die keuse van niestandaarditems is veral gerig op leksikale items met 'n beperking op grond van die dialektiese, kulturele, godsdienstige of tegniese veld waartoe hulle behoort. Die WAT bied 'n geldige verslag van 'n groot deel van die leksikon van Arikaans maar hierdie woordeboek moet ook beskou word as 'n waardevolle dokumentasie van die kultuurgeskiedenis van Afrikaans. Die WAT bevat kultuurspesifieke leksikale items as lemmas en gee 'n omvattende behandeling van hulle gebruik en betekenis asook 'n beskrywing van hulle historiese en kulturele waarde. Dit verhoog die WAT se waarde as 'n algemene naslaanbron. Die WAT is al dikwels in die verlede met reg gekritiseer vir sy oordrewe ensiklopediese benadering. Die behandeling van kultuurspesifieke items bevestig egter die belangrikheid van 'n omvattende en indringende leksikografiese behandeling waarin sowel die linguistiese as sekere buitelinguistiese kenmerke die aandag kry.

Ondanks die informatiewe benadering in die hantering van niestandaardgebruik word die WAT se stelsel steeds gestriem deur 'n puristiese vooroordeel wat vergelykbaar is met dié van vertalende Afrikaans-Engelse en ander eentalige Afrikaanse woordeboeke. As 'n woordeboek met 'n omvattende benadering 
het die WAT die volle spektrum van die leksikon van Afrikaans in sy bestek. Makrostrukturele omvattendheid impliseer die keuse van leksikale items wat verteenwoordigend is van alle style en registers, insluitende items uit die aansienlike versameling Engelse leenwoorde. Ongelukkig slaag die WAT nie daarin om die werklike omvang van die invloed van Engels op die Afrikaanse leksikon te reflekteer nie.

Getrou aan hulle normatiewe opdrag sal handwoordeboeke minder aandag gee aan die opname van leenwoorde aangesien hierdie woordeboektipe primêr gerig is op die weergawe van die standaardtaal. Daarenteen kan daar met reg van ' $n$ informatiewe woordeboek met 'n omvattende opdrag verwag word om 'n verteenwoordigende versameling van hierdie tipe leksikale items op te neem. Die opname van hierdie leenwoorde behoort gekomplementeer te word deur die aangawe van etikette ter aanduiding van hulle moontlike gebruiksbeperkinge. Deur 'n onvoldoende erkenning van die resultate van hierdie taalkontaksitusie boet die WAT se weergawe van die leksikon van Afrikaans in aan algemene geldigheid. Dit verminder die status van hierdie woordeboek as 'n omvattende bron van taalkundige inligting.

\subsection{Afrikaanse verklarende handwoordeboeke}

Ondanks die bogenoemde kritiek op die WAT se beleid ten opsigte van leenwoorde uit Engels is daar wel 'n hele aantal sulke lemmas in die WAT opgeneem; al is dit nie 'n verteenwoordigende versameling nie. Voorbeelde soos kothuis en krot is leenwoorde uit Engels wat verafrikaans is. Afrikaanse verklarende handwoordeboeke lewer 'n teleurstellende vertoning ten opsigte van die opname van leenwoorde uit Engels. Selfs met inagneming van die tipologiese kriteria wat die fokus in handwoordeboeke so sterk op die weergawe van standaardtaal plaas, kan die feitelike ignorering van hierdie komponent van die Afrikaanse leksikon nie verskoon word nie.

Woordeboeke soos die Verklarende Handwoordeboek van die Afrikaanse Taal (voortaan HAT) en die Nasionale Woordeboek (voortaan NW) moet hulle in hulle lemmakeuse aan die standaardtaal hou, maar die makrostrukturele keuse wat in hierdie woordeboeke geillustreer word, dui in baie gevalle op 'n verwronge siening van hulle tipologiese doelstelling. Hierdie probleem kan dikwels toegeskryf word aan 'n ongeldige interpretasie van die begrip "Standaardafrikaans". Deur vas te klou aan die tradisionele siening dat Afrikaans teen die invloed van Engels beskerm moet word, word hierdie begrip in puristiese terme verstaan, sonder inagneming van die sosiolinguistiese werklikheid en die prototipiese gebruik van Afrikaans. 'n Benadering wat teen die gebruik van leenwoorde uit Engels is, veroorsaak dat sulke woordeboeke dikwels 'n negatiewe normatiewe invloed het, vergelyk in hierdie verband Malkiel (1989: 64). 
Die puristiese vooroordeel in Afrikaanse verklarende handwoordeboeke voorkom nie net 'n geldige makrostrukturele keuse nie maar dit lei ook tot 'n oordrewe preskriptiewe en sterk normatiewe benadering. Selfs gevestigde leenwoorde, indien hulle wel opgeneem word, word dikwels op so 'n manier geëtiketteer dat woordeboekgebruikers dit as gestigmatiseerde items beskou wat in goeie taalgebruik vermy moet word. Vergelyk in hierdie verband die etikettering as Anglisisme van die lemmas geskeduleerd (-e) in NW en halfmas in HAT. In hierdie verband is die jongste uitgawe van die Verklarende Afrikaanse Woordebdek (voortaan VAW) 'n grootskaalse verbetering op die ander handwoordeboeke. Alhoewel VAW steeds onverteenwoordigend is wat sy leenwoordlemmas betref, neem hy tog heelwat meer Engelse leenwoorde op sonder om hulle per etiket te stigmatiseer. Daar word in hierdie publikasie ook baie minder voorskriftelike uitsprake gemaak.

Die preskriptiewe benadering in Afrikaanse verklarende woordeboeke is dikwels aangevul met en ondersteun deur die publikasie van normatiewe gebruikshandleidings. 'n Primêre doel van hierdie beperkte voorskriftelike woordeboeke was die bevordering van 'n suiwer variëteit van Afrikaans sonder tekens van Engelse invloed, vgl. Van der Merwe (1967) en Hiemstra (1980). Die hersiening van Van der Merwe (1967) Die korrekte woord deur Ponelis in 1982 en veral in 1991 was 'n belangrike leksikografiese deurbraak. Ponelis werk met 'n ander siening van die funksie van 'n preskriptiewe woordeboek en sy benadering lui 'n era van Afrikaanse woordeboeke in wat erkenning gee aan die Suid-Afrikaanse sosiolinguistiese werklikheid en die gevolge daarvan vir die leksikon van Afrikaans.

\section{3. 'n Nuwe perspektief op die preskriptiewe funksie in die leksikografie}

\subsection{Die gevestigde benadering}

In die leksikografie het die preskriptiewe benadering 'n lang en eerbiedwaardige tradisie. Dit is veral gevestig deur die houding wat Samuel Johnson ingeneem het in die beplanning en uiteindelike publikasie van sy woordeboek (Johnson 1747 en 1755). Sedertdien is woordeboeke steeds as taalkundige gesagsbronne beskou waarna die gebruiker opgesien het vir leiding ten opsigte van korrekte taalgebruik.

Die preskriptiewe benadering is nie net in algemene verklarende woordeboeke gevolg nie maar dit het ook 'n tipiese funksie van beperkte normatiewe woordeboeke geword. Een van die kenmerkende eienskappe van Afrikaanse beperkte woordeboeke wat op normatiewe leiding gerig is, is hulle sterk Anglisistiese vooroordeel (vgl. Gouws 1990; 61). Hierdie benadering het gelei tot pogings om Afrikaans op grond van puristiese oorwegings te reglementeer. Hierdeur het die normatiewe woordeboeke dieselfde soort fout begaan as verklarende Afrikaanse en vertalende Afrikaans-Engelse woordeboeke deurdat 
die makrostruktuur asook die leksikografiese adressering (vgl. Hausmann en Wiegand 1989 vir 'n verklaring van dié begrip) verteenwoordigend is van die leksikon van 'n ideale spreker en nie dié van 'n tipiese gebruiker van Afrikaans nie. Volgens Hanks (1990: 32) is dit die taak van die leksikografie om dit wat konvensioneel in ' $n$ taal is te ontdek en in woorde vas te vang. Hierdie benadering beklemtoon weer eens die funksie van 'n woordeboek om nie net taalkundige inligting te weerspieël met betrekking tot byvoorbeeld die grammatika, betekenis, uitspraak en etimologie van 'n versameling leksikale items nie, maar ook om verslag te doen van die sosiolinguistiese werklikheid van die betrokke taalgemeenskap. Binne die Suid-Afrikaanse taalsituasie beteken dit dat die Afrikaanse leksikograaf aandag moet gee aan die werklikheid van taalkontak en dat hy die uitwerking daarvan in sy woordeboek moet aantoon.

Tydens die vroeë jare van sy ontwikkeling moes Afrikaans sukkel om naas Engels as 'n onafhanklike taal gevestig en erken te raak. Alhoewel hierdie "stryd" suksesvol afgehandel is, is dit vir nog baie jare deur sommige leksikograwe en taalpuriste voortgesit. Voortgaande pogings om Afrikaans se posisie te verseker en te beveilig, is in beginsel lofwaardig en behoort aangemoedig te word. Waar sodanige pogings egter die invloed van die Suid-Afrikaanse taalkontaksituasie en veral die natuurlike invloed van Engels op Afrikaans as tekens van taalverval beskou en dit met felle weerstand benader, kan dit nóg linguisties nóg leksikografies sonder meer aanvaar word. Ongelukkig het hierdie benadering sterk inslag gevind. As gevolg daarvan vertoon baie Afrikaanse woordeboeke nog steeds 'n makrostrukturele versameling wat verteenwoordigend is van dit wat die leksikograaf as korrekte taalgebruik beskou en nie wat deur die taalkundige en sosiolinguistiese werklikheid as sodanig bewys word nie. Afrikaanse beperkte woordeboeke met 'n normatiewe opdrag het grootliks tot hierdie wanopvatting help bydra. Die onhoudbaarheid van so 'n benadering is reeds tydens die reaksie. op die verskyning van die Webster's Third New International Dictionary of the English Language in 1961 aangetoon. Vergelyk in hierdie verband Sledd en Ebbitt 1962.

\subsection{Die innoverende benadering}

Die eerste uitgawes van Die korrekte woord (voortaan DKW) (Van der Merwe 1967) het getrou gebly aan die toe geldende benadering van sterk voorskriftelikheid. Met die uitgawe van 1982 en veral dié van 1991 wat deur Ponelis bewerk is (Van der Merwe en Ponelis 1982, 1991), breek Ponelis weg van die tradisionele benadering en stel hy 'n nuwe furiksie vir hierdie woordeboek aan die orde. Die eerste uitgawes van DKW het 'n uitgebreide versameling Afrikaanse taalkwessies behandel met die klem op die normatiewe behandeling van leksikale items met spelling-, semantiese, gebruiks- of ander taalkundige probleme of eienaardighede. Die leksikografiese adressering is gerig op in 
keuse van problematiese leksikale items en die mikrostruktuur het bestaan uit in bespreking van sommige van die opvallendste aspekte van die lemmas.

Ponelis keur die opname van makrostrukturele items ook volgens hierdie kriteria maar die vasstelling van leksikale items waarmee gebruikers probleme mag ondervind, word nie puristies gemotiveer nie maar volgens bewyse uit die sosiolinguistiese werklikheid. Gevolglik sluit hy 'n uitgebreide versameling Engelse leenwoorde in en in die behandeling van hierdie items illustreer Ponelis 'n liberale houding waarin die klem geplaas word op maniere waarvolgens Afrikaans baat kan vind en reeds gevind het by die taalkontaksituasie. 'n Deeglik gemotiveerde houding teenoor taalverandering geld nie net in die keuse en behandeling van leenwoorde en in hulle aanvaarding as deel van die leksikon van Afrikaans nie, maar Ponelis illustreer sy siening ook deur die behandeling van ' $n$ andersoortige lemmatipe in DKW. Hy verbreed die bestek en omvang van die lemmaversameling op ' $n$ innoverende manier deur seleksiekriteria in te voer wat voorsiening maak vir die opname van meer as net leksikale items wat pragmatiese probleme bied.

Ponelis gaan verder as die bestaande tipologiese kriteria van normatiewe woordeboeke deur sy woordeboek te gebruik vir die bespreking van taalkwessies wat van groot belang is in 'n taalkontaksituasie. Die opname en behandeling van lemmas soos normering, Engelse invloed, taalverandering en variasie gee ' $n$ ander statuur áan DKW. Die adressering in hierdie artikels weerspieël 'n gesonde en objektiewe daarstelling van die leksikograaf se siening van hierdie kwessies en beklemtoon die funksie van DKW as 'n nuttige hulpmiddel by die gebruik van Afrikaans. In die voorwoord van die 1991-uitgawe verwys Ponelis na die insluiting van hierdie lemmas. Daardeur lig hy nie net die gebruiker in oor die vernuwing in DKW se makrostrukturele aard nie maar stuur hy hom na hierdie artikels. Die manier waarop Ponelis hierdie aktuele aangeleenthede bespreek en die onbevange benadering tot uiters delikate kwessies vorm die basis van die algemene benadering wat hy inneem in die normatiewe behandeling van lemmas in DKW.

Beperkte normatiewe woordeboeke lewer per tipologiese opdrag kommentaar op die staandaardvariëteit van die teikentaal. Die benadering wat in DKW gevolg word, ekspliseer 'n herinterpretasie van Standaardafrikaans deurdat 'n omvattender bestekbepaling ingevoer word. Gevolglik kan DKW 'n andersoortige normeringsinvloed uitoefen waarby die vestiging en normering van die standaardvariëteit van Afrikaans grootliks kan baat. Volgens Zgusta (1989: 70) kan die leksikograaf se houding teenoor taalverandering as die "fundamentum divisionis" beskou word wanneer dit gaan oor "n woordeboek se invloed op die standaard taal. DKW se innoverende benadering bied 'n welkome alternatief op die tradisionele normatiewe inhoud en die kunsmatige begrensing van Standaardafrikaans. 


\section{Die amptelike bereëling van die Afrikaanse spelling en erkenning van leenwoorde}

Die Afrikaanse woordelys en spelreêls (voortaan AWS) bied die amptelike spellingreglementering vir Afrikaans maar gee ook leiding ten opsigte van die erkenning van leenwoorde. Alle lemmas wat in die AWS verskyn, kan beskou word as erkende items van die Afrikaanse leksikon. As normatiewe woordeboek uit eie reg, bied die AWS riglyne ter ondersteuning van die leksikografiese erkenning van die invloed van die Suid-Afrikaanse taaldinamika op Afrikaans. In sy amptelike bereëling van die Afrikaanse spelling en erkenning van leenwoorde hou die Taalkommissie rekening met en bevestig hy die invloed van taalverandering.

Alhoewel die Taalkommissie in die 1991-uitgawe van die AWS heelwat leenwoorde, en veral ook Engelse leenwoorde, opgeneem het en daardeur erkenning gegee het aan hulle status as volwaardige leksikonitems van Afrikaans, is die vroeëre werk van die Taalkommissie dikwels gekenmerk deur 'n ietwat konserwatiewer benadering. Daar is geskroom om amptelike erkenning aan te veel leenwoorde uit Engels te gee. Gevolglik kon die normatiewe AWS nie die volle omvang van die invloed van Engels op Afrikaans weerspieël nie. Die liberaler benadering wat in die 1991-uitgawe gevolg is, lei tot die opname van talle Engelse leenwoorde soos derby, folk, rock en shandy. Die leksikografiese en sosiolinguistiese waarde van die opname van hierdie lemmatipe mag nooit onderskat word nie. Op die mees amptelike leksikografiese vlak word erkenning gegee aan die taalkontaksitusie en word die omvang van die linguistiese en sosiolinguistiese wisselwerking geëkspliseer. Die opname van leenwoorde geskied nie net ter erkenning van hulle status in Afrikaans nie maar ook ter aanduuiding van 'n algemener beginsel. Dit dui naamlik vir die gebruikers van die AWS daarop dat die voortgesette groei en ontwikkeling van Afrikaans afhanklik is van sy wisselwerking met die ander Suid-Afrikaanse tale en veral die wisselwerking met Engels. Hierdie benadering bied rigtinggewende leiding aan leksikograwe om nie in 'n Anglisistiese vooroordeel te stagneer nie maar om die werklikheid van die Suid-Afrikaanse taalsituasie te weerspieël.

\subsection{Afrikaanse woordeboeke en die AWS}

Omdat die AWS die amptelike spellinghandleiding van Afrikaans is, eerbiedig woordeboeke gewoonlik sy voorskrifte. Ook die mate van speling wat woordeboeke vertoon in hulle opname van Engelse leenwoorde is dikwels bepaal deur die benadering wat in die AWS gevolg is. Leksikograwe het die leenwoordkomponent van hulle woordeboeke se lemmaversameling so na as moontlik aan die AWS se geïmpliseerde grense gehou. Daardeur was hulle daarvan verseker dat hulle woordeboeke die amptelike erkende leksikon van 
Afrikaans bevat. Alhoewel dit vanuit 'n puristiese oogpunt 'n voorbeeldige benadering is, het dit ongelukkig daartoe gelei dat woordeboeke op makrostrukturele vlak te min nuwe inligting bevat het. Die AWS se riglyne is nagevolg maar woordeboeke het nie genoegsaam gepoog om 'n onafhanklike en innoverende rigting in te slaan nie. Dit kon byvoorbeeld gedoen gewees het deur die opname van 'n verteenwoordigende aantal leenwoorde ter illustrasie van die aktiewe groeikrag van Afrikaans en van die tipiese gebruik deur die meerderheid sprekers van Afrikaans.

In die 1991-uitgawe van die DKW volg Ponelis die meer liberale leiding van die nuwe AWS. Hierdeur gee DKW 'n objektiewer aanbieding van die sosiolinguistiese werklikheid van Afrikaans as enige ander beperkte normatiewe woordeboek. Maar DKW se leksikografiese erkenning van die taalkontaksituasie en sy invloed op Afrikaans oorskry die toeskietlikheid van die AWS. Ponelis verken en vertoon die werklike leksikale front van Afrikaans deur die opname van 'n wye versameling leenitems wat veral uit die informele register kom.

\section{DKW se weerspieëling van die taalkontaksituasie}

DKW bied ' $n$ verteenwoordigender behandeling van 'n belangrike onderafdeling van die Afrikaanse leksikon as enige ander beperkte, algemene verklarende of vertalende woordeboek deur die aandag te vestig op leksikale items uit die informele register en hulle te beskryf as deel van die algemene leksikon van Afrikaans.

Die omvang van DKW se leksikografiese bydrae ten opsigte van die invloed van taalkontak is nie beperk tot die insluiting en geimpliseerde erkenning van leenwoorde nie; selfs al is dít ' $n$ belangrike funksie van hierdie woordeboek. Die mikrostrukturele adressering in die artikels van die leengoedlemmas verteenwoordig 'n ewe waardevolle aspek wat bewys lewer van 'n vernuwende houding jeens taalkontak en die status van leengoeditems.

In die verlede het die adressering van Engelse leenwoorde in Afrikaanse woordeboeke dikwels blyke gegee van 'n negatiewe houding aan die kant van die leksikograaf. Dit geld verklarende en vertalende woordeboeke. Vergelyk in hierdie verband die etikettering as Anglisisme van die lemma karavaan aan die Afrikaans-Engelse kant van Tweetalige Woordeboek. Engelse leksikale items wat veral die meer informele register van Afrikaans binnegedring het, is as Anglisismes geëtiketteer. In Afrikaanse woordeboeke het hierdie etiket 'n stigmatiseringsinvloed. In die stryd om die vestiging van Afrikaans as 'n onafhanklike taal is daar moeite gedoen om Anglisismes op te spoor en uit te wis: 'n vorm van "leksikale suiwering". Alhoewel daar sedertdien ingrypende houdingsveranderings was en die heksejag op Anglisismes grootliks gestaak is, het die term "Anglisisme" steeds 'n negatiewe konnotasie. Lemmas wat so geëti- 
ketteer word, word deur die gewone woordeboekgebruiker as ongewenste elemente beskou.

In DKW se artikel van die lemma Engelse invloed beweer Ponelis dat dit onsinnig sou wees om die invloed van Engels op Afrikaans ongehinderd sy gang te laat gaan. Dit sou die einde van Afrikaans kon beteken. Dit het, aldus Ponelis (Van der Merwe en Ponelis 1991: 64), ewe min sin "om Anglisismes fanaties uit te ruik en te probeer elimineer". So 'n optrede vervreem die taalgebruiker van sy taal. Dit hou eweneens rampspoedige gevolge vir Afrikaans in. Ponelis se siening is relevant vir alle Afrikaanse leksikografiese projekte. Woordeboeke behoort die invloed van Engels op Afrikaans op so 'n manier te behandel dat die leksikograaf se houding nie die lojale gebruiker van Afrikaans vervreem nie. ' $n$ Onsensitiewe behandeling van taalbeïnvloeding in woordeboeke kan 'n ondermynende invloed hê op die houding van die taalgemeenskap vir wie die woordeboek saamgestel is. Zgusta (1989: 73) beweer dat daar sekere tipes diglossie bestaan waar die geskrewe standaardtaal, en selfs die gesproke standaardtaal in sy formeler registers, argaies is in vergelyking met die alledaagse omgangstaal. Woordeboeke moet erkenning gee aan die bestaan van verskillende registers binne die standaardvariëteit van Afrikaans. Dit beteken dat ook die omgangstaal geakkommodeer moet word en dat daar gevolglik 'n leksikografiese bewerking van onder meer leenwoorde moet wees. In hierdie verband tree DKW voorbeeldig op. Hierdie soort benadering werk die vervreemding van die tradisionele siening van Standaardafrikaans teë. Dit gee nie net erkenning aan 'n ruimer domein van hierdie variëteit van Afrikaans nie maar bevestig eweneens die aansprake van 'n groot deel van die Afrikaanse taalgemeenskap op die aanvaarbaarheid van hulle normale taalgebruik as deel van die erkende en aanvaarde variëteit.

\section{Leengoeditems in DKW}

\subsection{Leenwoorde}

Die houding wat in die artikel van die lemma Engelse invloed uiteengesit word, word konsekwent toegepas in DKW se behandeling van Engelse leenwoorde en ander fasette van taalbeinvloeding, byvoorbeeld in die opmerkings oor die plasing van aksent waar die uitspraak van 'n woord onder Engelse invloed tot aksentverskuiwing lei. Vergelyk in hierdie verband die opmerkings in die artikels van die lemmas kontak en konteks. Leenwoorde soos boobytrap, ladybird, lover, mechanic, O.K., rumpsteak, scrap en tissue is enkele van die Engelse leksikale items wat as lemmas opgeneem is. DKW erken nie net hulle optrede in Afrikaans nie maar die manier waarop Ponelis hulle behandel, bevestig hulle status as volwaardige Afrikaanse leksikale items. Dit blyk byvoorbeeld uit die behandeling van tissue: "Daar is 'n groot behoefte aan tissue (tiesjoe) om 'papiersakdoekie' aan te dui." Hierdie formule- 
ring is kenmerkend van die DKW-benadering wat gebaseer is op die beginsel van funksionele ontlening.

In sommige artikels motiveer Ponelis die behoefte aan 'n spesifieke leenwoord, byvoorbeeld in die artikel van die lemma jet-set waar hy sê dat dit nie maklik gaan om ekwivalente te kry vir jet-set en jet-setter nie. Die Afrikaanse stralerjakker(s) is onreëlmatig gevorm en behoort eintlik stralerjakkeraar(s) te wees. Op soortgelyke manier betoog hy ten gunste van die leenwoord cater en sy verafrikaanste spelling kyter. Ponelis stel dit onomwonde dat 'n Anglisismevrees daartoe gelei het dat hierdie woord vervang is deur spysenier. Hy verduidelik dan ook hoekom spysenier nie die mas opkom nie en hoe cater/kyter probleemloos by die Afrikaanse klanksisteem aangepas is en reeds algemeen gebruiklik is in die idiomatiese uitdrukking nie vir iemand se nonsens cater nie. Die gebruik van leenwoorde in die idioomskat van die ontvangertaal dui enersyds op die behoefte aan sodanige elemente en andersyds op die mate waarin hulle reeds ingeburger is in die gewone spreektaal.

Die onbevooroordeelde houding ten opsigte van Engelse leenwoorde word verder geëkspliseer in DKW se behandeling van leenwoorde wat algemeen gebruiklik is naas of in plaas van bestaande Afrikaanse woorde waar daardie leenwoord tog ' $n$ wins vir Afrikaans is. Ponelis sluit die lemma facelift in en die enigste behandeling wat hierdie lemma kry, is die Afrikaanse ekwivalent ontrimpeling. Die lemma jet lag kry die vertaalekwivalente lugroes en vlugtamheid. Hierdie soort behandeling impliseer dat sowel die leenwoorde as hulle Afrikaanse ekwivalente gangbare Afrikaans is. Woordeboeke behoort indringender aandag te gee aan hierdie fase van die taalbeïnvloedingsproses. Dit is ' $n$ manier waarop die leksikograaf verslag kan doen van die dinamika van taalverandering.

Die omvang van Engelse invloed word op verskillende maniere in DKW weergegee. Die eenvoudigste manier is die opname van leenwoorde soos die vermelde boobytrap, ladybird, O.K., ens. Leenwoorde is onderhewig aan aanpassings by die Afrikaanse taalpatroon en talle woorde het verafrikaansing ondergaan. DKW vertoon 'n verskeidenheid aanpassings waaronder spellingaanpassings, bv. orraait en oukei; deeltjiewerkwoorde met 'n Afrikaanse deeltjie en 'n Engelse werkwoordelike komponent, bv. uitfigure (gegee in die artikel van die lemma Engelse invloed) en rondshunt; 'n spellingaanpassing en 'n gedeeltelike vertaling, bv. opstêrs; multileksikale lemmas wat uit 'n Afrikaanse en 'n Engelse komponent bestaan, bv. finish en klaar en iemand sy pedigree vertel. Verskeie van hierdie leenitems, bv. opstêrs, rondshunt en iemand sy pedigree vertel vertoon opmerklike semantiese verskille tussen hulle optredes in Afrikaans, Suid-Afrikaanse Engels en Standaard Britse Engels.

DKW doen verslag van taaldinamika deur te wys hoe die aanpassing en uiteindelike assimilasie van Engelse woorde en uitdrukkings die leksikon van Afrikaans verryk. In hierdie proses beperk DKW sy bestek nie tot die formele en puristiese taalgebruik nie maar verleen ook erkenning aan die werklike taalgebruik en die informele register van Afrikaans. Die Engelse item show off het 
verskillende Afrikaanse vertaalekwivalente, bv. pronk en spog. In die informele register van Afrikaans het die leenwoord afshow 'n hoë gebruiksfrekwensie. Hierdie deeltjiewerkwoord bestaan uit die Afrikaanse deeltjie af en die Engelse werkwoordelike element show. Die Afrikaanse suffiks -erig is baie produktief in die vorming van bywoorde en adjektiewe. In die artikel van die lemma afshow wys Ponelis op die gebruik van hierdie suffiks in die vorming van die afleiding afshowerig. Ponelis sê dat afshow in die omgangstaal deeglik gevestig is maar nie in versorgde taal nie. Deur hierdie opmerking hou DKW hom aan sy normatiewe en pragmatiese opdrag.

Ondanks die insluiting en positiewe evaluering van 'n groot verskeidenheid leenwoorde vervul DKW steeds 'n preskriptiewe funksie deur in baie artikels aan te dui dat ' $n$ bepaalde leenwoord as 'n ongewenste Anglisisme beskou moet word. Die DKW-benadering verskil egter aansienlik van dié van ander woordeboeke op grond van die goed gebalanseerde en objektiewe evaluering en interpretasie van die eise, veranderinge in en werklikhede van die SuidAfrikaanse taalsituasie.

\subsection{Leenvertalings}

Een van die terreine waar die invloed van Engels op Afrikaans op sy produktiefste is, is by die vorming van leenvertalings. Waar twee tale as amptelike tale deur een gemeenskap gebruik word, is dit onvermydelik dat die konstante taalkontak nie net tot die oorname van leenwoorde sal lei nie maar ook tot die regstreekse vertaling van komplekse leksikale items soos samestellings en idiomatiese uitdrukkings. Afrikaans het baie leksikale items wat leenvertalings is en wat regstreeks na die Engelse vorme herlei kan word. Soos met ander aspekte van taalbeinvloeding in Suid-Afrika die geval is, is herdie tipe taalbeïnvloeding eweneens 'n tweerigtingproses wat Suid-Afrikaanse Engels ook grootliks beinvloed.

Die voorkoms van leenvertalings in Afrikaans en in Suid-Afrikaanse Engels en die manier waarop hierdie verskynsel in vertalende, verklarende en beperkte normatiewe woordeboeke hanteer word, is belangrike merkers van die verhouding tussen die heersende kulturele en linguistiese kontak. Oorspronklik was daar opvallende kulturele verskille tussen Afrikaans- en Engelssprekende Suid-Afrikaners. Voortgesette sosiale kontak tussen hierdie twee sprekersgroepe het gelei tot 'n wisselwerking tussen die twee tale en die twee kulture. Volgens Kromann e.a. (1991: 2712) moet woordeboeke kultuur interpreteer. As daar tussen twee tale 'n verhouding van sero-ekwivalensie vir 'n gegewe kultuurspesifieke item bestaan, moet die leksikograaf voorstelle doen om moontlike vertaalekwivalente te vestig. So 'n benadering het definitiewe implikasies vir die preskriptiewe/deskriptiewe funksie van woordeboeke. Vroeëre vertalende Afrikaans-Engelse woordeboeke het op 'n soortgelyke 
manier die taal- en kulturele invloed probeer verwerk deur vertaalekwivalente te probeer skep. Dit het dikwels tot uiters onnatuurlike produkte gelei.

Mettertyd kon die taalgrens tussen Afrikaans- en Engelssprekende SuidAfrikaners nie meer as 'n kulturele skeiding beskou word nie. Die saambestaan binne 'n enkele geografiese en sosiale gemeenskap het tot kulturele assimilasie gelei. Alhoewel klein kulturele verskille tussen die twee taalgroepe steeds binne sekere sosiale en geografiese groeperinge bestaan, kan Afrikaansen Engelssprekende Suid-Afrikaners as 'n enkele kulturele gemeenskap beskou word. Hierdie kulturele assimilasie en die status van Afrikaans en Engels as die twee amptelike landstale het verreikende implikasies gehad vir die invloed en bestek van taalkontak.

Tydens die vroeë dekades van hierdie eeu was daar by sommige mense 'n behoefte om Afrikaans en Engels met verskillende kulture te assosieer. Hierdie gevoel is onder meer bewerk deur vyandigheid tussen die twee taalgroepe in die jare van die Anglo-Boereoorlog. Die vyandiggesindheid tussen sommige sprekers van die twee taalgroepe en hulle begeerte om Afrikaans en Engels met verskillende kulture te vereenselwig, het gelei tot pogings deur Afrikaanse linguiste en leksikograwe om 'n veldtog van linguistiese suiwering op Afrikaans toe te spits. Een van die doelstellings van die puriste was om Afrikaanse ekwivalente vir elke Engelse woord en uitdrukking te skep en om die alleengebruik van die eg Afrikaanse items te bevorder. Woordeboeke moes behulpsaam wees in die bereiking van hierdie onrealistiese ideaal.

Die tweetalige Afrikaanssprekende se maklike toegang tot Engels en die omvattendheid van die Engelse leksikon het gelei tot die regstreekse vertaling van talle Engelse samestellings en uitdrukkings. Hierdie leenvertalings het 'n hoë gebruiksfrekwensie in Afrikaans. Puriste het die Afrikaanse leksikon noukeurig gefynkam op soek na en ter onderdrukking van sulke leenvertalings. Woordeboeke is gebruik om Afrikaanse ekwivalente te skep en hulle gebruik te bevorder ter vervanging van die leenvertalings. Hierdie pogings was gedoem tot mislukking want nóg 'n woordeboek nóg 'n preskriptiewe taalkundige kan die dinamika van taalverandering keer of van koers laat verander. Die leksikograaf se taak is nie om woorde te skep nie maar om die werklike en konvensionele taalgebruik te weerspieël.

Die evaluering van leenvertalings in Afrikaans mag nie kategories gedoen word nie maar moet op ' $n$ item-vir-item-basis geskied. Daar is talle ongewenste leenvertalings wat in kompetisie is met gevestigde Afrikaanse items. DKW sluit ' $n$ hele versameling sulke items in maar in hulle behandeling word dit uitdruklik gestel dat hierdie vorme as Anglisismes beskou moet word. Verwysings word telkens verstrek na die korrekte Afrikaanse vorm. Die volgende voorbeeld lewer daarvan bewys hoe DKW in hierdie opsig sy normatiewe funksie uitvoer. Die lemma aanvat word as Anglisisme gemerk met ' $n$ verwy sing na die aanvaarde Afrikaanse vorm aanspreek. Op 'n soortgelyke manier word die lemma en so aan gemerk en die Afrikaanse item en so meer/en dies meer word as korrektief daarop verstrek. Hierdie werkswyse word op 'n kon- 
sekwente manier in DKW gevolg. Maar ' $n$ leenvertaling is dikwels ' $n$ waardevolle bydrae tot die leksikon van Afrikaans en waar leenvertalings so 'n funksionele rol vervul, moet woordeboeke op 'n sistematiese en objektiewe manier daarvan verslag doen. In sulke gevalle sou daar met vrug nog aandag gegee kon word aan subtiele betekenis- en gebruiksverskille wat wel tussen die woordpare mag bestaan.

Ongelukkig het ' $n$ bevooroordeelde beperking op die bestek en invloed van taalkontak in baie Afrikaanse woordeboeke gelei tot 'n minderwaardige behandeling van dié leksikale kategorie. Pogings van leksikograwe om Afrikaans van leenvertalings uit Engels te suiwer het gelei tot die leksikografiese vergestalting van onnatuurlike en onkonvensionele items wat geskep is in 'n kunsmatige poging om die Afrikaanse leksikon uit te brei sonder die insluiting van leenvertalings uit Engels. Afrikaanse woorde soos die volgende voorbeelde (almal uit Groot Woordeboek/Major Dictionary: voortaan GW), wat beswaarlik algemene gebruikstatus geniet het, is geskep om die gebruik van die leenvertalings wat tussen hakies gegee word, teë te werk: bruismelk/skuimmelk/roomysmelk (melkskommel), knormoer (selfaansitter), wisselwiel (spaarwiel) en ysterware (hardeware). Daarbenewens is daar in sommige gevalle op Nederlandismes teruggeval wat ewe onafrikaans is. Vergelyk in hierdie verband die GW-voorbeelde bestelkantoor (pakkettekantoor) en briewebesteller (posman). In sulke gevalle vervul die woordeboeke, volgens Zgusta (1989: 70), 'n argaisseringsfunksie deurdat hulle nie net die verandering in die standaardvariëteit wil voorkom nie maar verouderde en ongebruiklike vorme weer wil invoer en in die leksikon herbevestig.

DKW bied 'n nuwe perspektief op die status van leenvertalings in Afrikaans. Ondanks die kritiek op talle leenvertalings wat as Anglisismes gemerk word en wat van 'n gewenste Afrikaanse ekwivalent voorsien word, gee hierdie woordeboek erkenning aan die bestaansreg van 'n uitgebreide versameling van hierdie tipe leksikale items. Dit strook met die behoeftes en eise van die aktiewe taalgebruikers. Die DKW-gebruiker kry nou die versekering, dikwels met ' $n$ gepaardgaande taalkundige motivering, dat hy daarop geregtig is om leenvertalings soos die volgende te gebruik - in plaas van die puristiese vorm wat telkens tussen hakies gegee word: boekmerk (boeklêer/leeswyser), broodlyn (armoedslyn/bestaansminimum) en valstande (kunsgebit). Die lemma lokettreffer staan in skerp kontras met die onnatuurlike TW-inskrywings kasstuk, suksesstuk, kastreffer en kassukses. Dikwels verstrek DKW wel die puristiese Afrikaanse ekwivalente van bepaalde leenvertalings maar wys dan op hulle ongebruiklikheid, nie-Afrikaansheid of onnatuurlikheid.

Leenvertalings van idiome en vaste uitdrukkings word op 'n soortgelyke manier behandel. Waar 'n goeie en lewensvatbare Afrikaanse ekwivalent bestaan en gebruik word en waar die leenvertaling nie 'n werklike bydrae lewer nie, word die leenuitdrukking gemerk. Die uitdrukking Bloed is dikker as water word as Anglisisme gemerk en die Afrikaanse ekwivalente Waar bloed nie kan loop nie daar kruip dit/Die hemp is nader as die rok word ver- 
strek. Daarnaas word die leenvertaling 'n perd van 'n ander kleur as 'n gevestigde Engelse leenvorm aangedui. Eweneens word die uitdrukking op roep as 'n gevestigde leksikonitem behandel met die byvoeging dat hierdie leksikale item geen ekwivalent in Afrikaans het nie.

\section{3 'n Funksionele normatiewe benadering}

Die gevolge van taalkontak word in DKW so ver as moontlik op 'n objektiewe en onbevooroordeelde manier aangebied maar sonder dat dié woordeboek aan normatiewe krag inboet. Ponelis sluit 'n wye verskeidenheid Engelse en ander leenwoorde in en beoordeel elkeen telkens op sy eie meriete maar dan veral in terme van sy funksie en bydrae tot Afrikaans. Dit bring mee dat sowel gewenste as ongewenste onlenings lemmastatus kry, met die leksikografiese adressering wat die evaluatiewe verskille ekspliseer. Ongewenstheid word vasgestel op grond daarvan dat die betrokke leksikale item nie 'n funksionele optrede in Afrikaans het nie en daarom nie as deel van die Afrikaanse leksikon erken of bevestig moet word nie. Dit blyk byvoorbeeld uit Ponelis se behandeling van die lemmas malvalekker en zip. Die volledige bewerking van die eerste voorbeeld is: "Die Afrikaans vir marshmellow." en van die laasgenoemde lemma word onder meer gesê: "Ons het geen behoefte aan hierdie woord nie, want daar is die kort ekwivalent rits..." In sulke artikels beantwoord DKW steeds aan sy normatiewe opdrag maar die evaluering berus op die funksionele bydrae en waarde wat die spesifieke leksikale item vir Afrikaans het.

'n Belangrike deel van DKW se normatiewe leiding is om kritiese uitsprake te maak oor die motivering vir die gebruik van sekere Engelse leenwoorde waar die gebruik van hulle Afrikaanse ekwivalente verwag sou kon word. Die mikrostrukturele behandeling van die lemma leftovers is beperk tot die volgende stelling: "Dit is ' $n$ raaisel waarom hierdie leenwoord ons eie oorskiet/oorskietkos in die omgangstaal verdring." In sommige artikels gee Ponelis onwillig toe dat 'n spesifieke Engelse item uiteindelik erkenning sal moet kry omdat dit 'n hoër gebruiksfrekwensie as sy Afrikaanse vertaalekwivalent het. Die lemma idle word soos volg behandel: "As luier die pyp nie rook nie, sal idle maar teen wil en dank erken moet word." In ander artikels word leenwoorde verstrek maar dit word gestel dat die Afrikaanse ekwivalent besig is om veld te wen. Vergelyk die lemma masking tape se behandeling: "Die gebruik van maskeerband neem toe, maar masking tape is 'nog steeds baie lewenskragtig."

Hierdie benadering illustreer nogmaals die waarde van 'n woordeboek as ' $n$ instrument om die dinamika van taalverandering en linguistiese interaksie te weerspieël en te dokumenteer. 'n Mens sou wou sien dat dié beleid in volgende uitgawes nog uitgebrei moet word. 


\section{Ten slotte}

Die ontwikkeling in die Afrikaanse leksikografie het 'n punt bereik waar woordeboeke begin om verslag te doen van die linguistiese, sosiolinguistiese en kulturele werklikheid. Dit word onder meer bereik deur die insluiting en behandeling van leksikale items wat die voortdurende wisselwerking in 'n meertalige en multikulturele omgewing verteenwoordig. So 'n benadering verhoog die gehalte van woordeboeke en dra by tot hulle status as gesaghebbende bronne van inligting.

\section{Verwysings}

Bosman, D.B. e.a. (Reds.). 19848. Tweetalige Woordeboek/Bilingual Dictionary. Kaapstad: Tafelberg. De Villiers, Meyer e.a. 19877. Nasionale Woordeboek. Kaapstad: Nasou.

Gouws, Rufus H. 1990. Information Categories in Dictionaries, with Special Reference to Southern Africa. Hartmann, R.R.K. (Red.). 1990: 52-65.

Gouws, Rufus H. 1993 (ter perse). Dictionaries and the Dynamics of Language Change.

Gove, P.B. (Red.). 1961. Webster's Third New International Dictionary of the English Language. Springfield, Massachusetts:' Merriam Webster.

Hanks, Patrick. 1990. Evidence and Intuition in Lexicography. Tomaszczyk, J. en B. Lewandowska-Tomaszczyk (Reds.). 1990: 31-41.

Hartmann, R.R.K. (Red.). 1990. Lexicography in Africa. Exeter: University of Exeter Press.

Hausmann, F.J. en H.E. Wiegand. 1989. Component Parts and Structures of General Monolingual Dictionaries: A Survey. Hausmann, F.J. e.a. (Reds.). 1989-1991: 329-360.

Hausmann, F.J. e.a. (Reds.). 1989-1991. Wörterbücher. Dictionaries. Dictionnaires. An International Encyclopedia of Lexicography. Berlyn: Walter de Gruyter.

Hiemstra, L.W. 1980. Die juiste woord. Kaapstad: Tafelberg en Nasou.

Johnson, S. 1747. The Plan of a Dictionary of the English Langunge. Faksimilee-uitgawe 1970. Menston: The Scolar Press.

Johnson, S. 1755. A Dictionary of the English Language. Londen: J. \& P. Knapton, T. \& T. Longman e.a.

Kritzinger, M.S.B. e.a. 198613. Groot Woordeboek/Major Dictionary. Pretoria: J.L. van Schaik.

Kromann, H-P. e.a. 1991. Principles of Bilingual Lexicography. Hausmann, F.J. e.a. (Reds.). 1989-1991: 2711-2728.

Labuschagne, F.J. en L.C. Eksteen. 19938. Verklarende Afrikaanse Woordeboek. Pretoria: J.L. van Schaik.

Malkiel, Y. 1989. Wörterbuch und Normativität. Hausmann, F.J. e.a. (Reds.). 1989-1991: 63-70.

Odendal, F.F. 19792. Verklarende Handwoordeboek van die Afrikaanse Taal. Doomfontein: Perskor.

Sledd, J. en W.R. Ebbitt. (Reds.). 1962. Dictionaries and That Dictionary. Chicago: Scott, Foresman and Company.

Taalkommissie van die SA Akademie. 19918. Afrikaanse woordelys en spelreëls. Kaapstad: Tafelberg. 
Tomaszczyk, J. en B. Lewandowska-Tomaszczyk. (Reds.). 1990. Meaning and Lexicography. Amsterdam: John Berjamins.

Van der Merwe, H.J.J.M. 1967. Die korrekte woord. Pretoria: J.L. van Schaik.

Van der Merwe, H.J.J.M. en F.A. Ponel is. 19826. Die korrekte woord. Pretoria: J.L. van Schaik. Van der Merwe, H.J.J.M. en F.A. Ponelis. 1991'. Die korrekte woord. Pretoria: J.L. van Schaik. Woordeboek van die Afrikaanse Taal. Pretoria: Staatsdrukker.

Zgusta, L. 1989. The Role of Dictionaries in the Genesis and Development of the Standard. Hausmann, F.J. e.a. (Reds.). 1989-1991: 70-79. 